\title{
Women's entrepreneurship and local wisdom: The role of sustainable subjective wellbeing
}

\author{
I Gusti Ayu Purnamawatia, Made Suyana Utama ${ }^{a}$, I Wayan Suartana ${ }^{a}$ and Anak Agung Istri Ngu- \\ rah Marhaeni ${ }^{a^{*}}$
}

\begin{abstract}
${ }^{a}$ Doctoral Program in Economic, Udayana University, Indonesia
\section{H R O N I C L E}

\section{Article history:}

Received: June 30, 2020

Received in revised format:

June 302020

Accepted: July 12, 2020

Available online:

July 20, 2020

Keywords:

Woman entrepreneur

Subjective well-being

Local wisdom

\section{A B S T R A C T}

The research objective is to analyze the effect of women's empowerment, bricolage, and entrepreneurial orientation, in improving business performance and life satisfaction perceived by women entrepreneurs through subjective well-being. The sampling technique used is non-probability sampling and data collection methods through non-behavioral observation, structured interviews, and in-depth interviews. The research data were sourced from primary data through questionnaires and interviews and used a sample of 113 weaving entrepreneurs in Bali Province. Data analysis techniques with descriptive statistics and Structural Equations Model using Partial Least Square. The results showed that: women's empowerment and entrepreneurial orientation influences business networks. Entrepreneurial orientation, business networks and bricolage have a significant effect on business performance. Empowering women has no significant effect on business performance. But overall, women's empowerment, entrepreneurial orientation, business networks and business performance have a significant effect on subjective well-being. Bricolage strengthens the role of women's empowerment in the business performance of weaving owners. The positive influence of women's empowerment and entrepreneurial orientation through business networks on business performance and subjective well-being. Business performance mediates the influence of women's empowerment, entrepreneurial orientation, and business networks on subjective well-being.
\end{abstract}

C) 2020 by the authors; licensee Growing Science, Canada

\section{Introduction}

Women entrepreneurs in developing countries face several obstacles, ranging from discrimination and social barriers to restrictions in making decisions, working and traveling (Terjesen \& Elam, 2012). Therefore, greater ability in managing companies is very important to overcome obstacles faced by women entrepreneurs. Efforts are made to overcome entrepreneurial obstacles through maximum control, increase self-determination to overcome obstacles, and have confidence in influencing company performance, all three are elements of empowering women entrepreneurs that can affect the performance of women and medium-sized small businesses in developing countries. Moving on from traditional gender-based comparisons, namely men and women, perceived empowerment in entrepreneurial efforts, there are several things that cause women entrepreneurs in developing countries to be more successful than others. The company's performance is influenced by empowerment which is strengthened by the role of bricolage. Bricolage according to Baker and Nelson (2005) is an act of applying a combination of existing resources to new problems and opportunities and their possibilities as an entrepreneurial motivator and valuable innovation in a resource-constrained environment. Through increased empowerment, increasing bricolage enables ease of networking, combining resources, with the aim of improving performance. Business network is a relationship between business actors (owners) with people or parties who support business continuity, such as suppliers of raw materials (suppliers), distributors, village apparatus and legal institutions. SMEs can achieve collective efficiency through social relations, harmonization, and synergy with external parties (Najib \& Kiminami, 2011) which in research are termed 
collaborative networks (Zeng et al., 2010) or networks (Clifton et al. 2010), cooperation (Najib \& Kiminami, 2011). To make SMEs more competitive, the problems in general are limited resources owned such as the budget, the quality of human resources, technology and low access to information, so that the management of SMEs will increasingly depend on external parties.

Socio-economic development makes subjective well-being an important issue which is the goal that must be achieved. Derived from Quality of Life (QOL), SWB has become a different concept from time to time representing a subjective measurement of well-being (Holm et al., 2017). Based on the views of some researchers, the subjective well-being domain represents the realm of individual emotional states in terms of satisfaction, happiness, positive and negative influences about life (Diener et al., 2017; Siedlecki et al., 2014). Bali Province with the excellence of creativity and art possessed by its people has the opportunity to develop the craft industry to its full potential. The rapid development of Balinese weaving crafts is a big challenge for Balinese women to maintain its sustainability. Weaving crafts closely with the traditions and culture of Balinese people. In addition, this industry also absorbs a lot of labor which is categorized as Small and Medium Enterprises. A growing problem in society is that the decline in the value of weaving production is low market demand. The decline in fluctuations occurred in 2008-2010. The reason is the difficulty of raw materials, expensive yarn prices, and quality that is not in accordance with craft production standards. The specificity of weaving must be maintained because the local cultural elements in it that provide added value and uniqueness to the local weaving industry. The process of making Bali weaving still involves rituals to produce quality fabrics, in addition to getting a piece of cloth, people who buy weaving also have cloth that is full of stories and meanings. The resulting motifs depict more flora, fauna, and puppet characters who often appear in the mythologies of Balinese stories. Marketing of weaving cloth is not only a piece of cloth, but cloth that has a story, and this has become its own competitiveness for weaving in the world market. The ability to create more creative weaving can be done through awareness of the surroundings (Tri Hita Karana). The nature of tradition and community life in Bali in general are full of religious ceremonies and philosophical values. The existence of Tri Hita Karana's spiritual philosophy, namely three things as a cause of well-being. Its implementation can shape the character of Balinese who care about the relationship between humans and God (parahyangan), humans with each other (pawongan), and humans with the environment (palemahan). The harmonization of life lived by weaving entrepreneurs inspired the creation of more attractive weaving designs. Concern for the natural surroundings gives the ability to see change more quickly (Gede, 2010). Woven fabric is not just cloth that has artistic value. Woven fabric also has a very high economic value. The spirituality values contained in the Tri Hita Karana teachings prioritize the balance between cultural performance and business performance in economic activities. Economic activity is closely related to entrepreneurship. Tri Hita Karana's spiritual philosophy is the main foundation in the dimension of subjective well-being for the weaving industry in Bali (Budiasih \& Suardikha, 2017).

This research is motivated by poverty phenomenon which is the main problem being faced by developing countries including Indonesia. Multi-dimensional social phenomena make poverty closely related to economic, structural, cultural, psychological, and ecological dimensions. This makes women and children victims of poverty. Government efforts in empowerment involving women, so far have not been maximized. Every program held aims to empower women, it seems to be a normative program and non-optimal. The specificity of weaving crafts must be maintained because the local cultural elements in it provide added value and uniqueness to the local weaving industry.

\section{Literature Review and Hypotheses Development}

Related to the weaving industry management in Bali Province is mostly managed by women. It has to do with gender equality which slowly shifts the paradigm of subordination of men to women, especially in Balinese society which is thick with cultural elements. Women can contribute sufficient income in improving the economy and family welfare. The uniqueness and distinctiveness of Balinese culture is inseparable from patriarchal culture which originates from the patrilineal system of Balinese kinship. In Balinese social life and also in its role in the community. Woman empowerment according to Hubeis (2010) is an effort to improve the status and role of women in national development, including the quality and independence of organizations managed by women. However, subjective wellbeing has fallen sharply for members with new autonomy when it is met with relatively conservative social gender norms among non-members. The mechanism of social sanctions plays an important role in overcoming negative heterogeneous impacts on subjective well-being, as evidenced by crossscientific qualitative research in the field of women's empowerment. Several empirical studies have shown a positive relationship of empowerment to motivation, creativity and innovation (Zhang \& Bartol, 2010). A network, is an action carried out between individuals and other organizations (Dollinger, 1999) and networking is an alternative to using internal resources. Business networks are very important, in line with the current economic situation that is increasingly competitive, through the ease of accessing information, resources, markets, and technology (Gulati et al., 2000). Bricolage has the meaning of maximizing something with existing resources when solving problems and exploring opportunities (Domenico et al., 2010). The idea of bricolage in general is limited by the available resources to improvise, social value creation, stakeholder participation, and persuasion. In this context, Senyard et al. (2014) found that companies involved in bricolage had a significant effect on new product innovation under resource constraints, thus, bricolage has a big role in innovating with limited resources. Furthermore, Cunha (2014) stated his findings regarding a creative approach to scarcity of resources that is useful for entrepreneurship development. Increased empowerment has a positive influence on company revenue, which is 
strengthened by the role of bricolage. Research by Linna (2013) disclose the component bricolage which consists of three parts, and relates to the stages of the innovation process: a combination of social mindsets; satisfaction with the availability of resources; and improvisation. Bojica et al. (2015) explores the relationship between bricolage studied in the context of extreme resource scarcity and its effect on business performance. The results of his research found that bricolage has a significant effect on company performance.

Business performance as an organization's ability to utilize its resources includes knowledge, human resources, and raw materials for the purpose of achieving effectiveness and efficiency (Daft, 2010). Business performance will be analyzed through an objective or subjective perspective. Disclose that financial data is preferred, but companies are not always willing to disclose confidential data unless the law requires them to disclose it to the public. Measurement of business performance becomes the basis for decision making for interested parties. The current view of well-being is expressed holistically and contextually, describing a sustainable relationship between individuals, and their social environment (Knoop \& Delle, 2013). Siedlecki et al. (2013) stated that subjective well-being as an idea of cognitive decisions that reflects the satisfaction of one's life and an evaluation of emotions that are classified as positive emotions and negative emotions. Welfare indicators are compiled not only to describe conditions of material prosperity (well-being), but also are more towards conditions of subjective well-being or happiness. Entrepreneurial orientation is an organization's strategic resource with the potential to produce competitive advantage. Entrepreneurship is able to motivate people to create breakthroughs in commercial and social innovation. Some key dimensions of entrepreneurial orientation are independence, a desire to innovate and take risks, an aggressive attitude towards competitors, and proactively facing market opportunities. In the end the aspects of the company are closely related to entrepreneurial orientation and business performance. Entrepreneurial orientation is a combination of three dimensions: innovation, proactivity, and risk taking. These three dimensions are based on Miller (2011). The characterization used is that an entrepreneurial company is a company engaged in product market innovation, doing a rather risky business, and first produced proactive innovations that beat competitors. SMEs collectively realize efficiency through the support of specialization, social relations, and synergy with other parties (Zeng et al., 2010; Clifton et al., 2010; Gronum et al., 2012; Indarti \& Postma, 2013; Najib \& Kiminami, 2011).

Based on conceptual framework developed in this study, the hypotheses of this research can be formulated:

$\mathrm{H}_{1}$ : Women's empowerment and entrepreneurial orientation have a positive effect on business networks.

$\mathrm{H}_{2}$ : Empowerment of women, entrepreneurial orientation, business networks and bricolage have a positive effect on business performance.

$\mathrm{H}_{3}$ : Empowerment of women, entrepreneurial orientation, business networks and business performance have positive effects on subjective well-being.

$\mathrm{H}_{4}$ : Bricolage moderates the positive influence of women's empowerment on business performance.

$\mathrm{H}_{5}$ : The business network mediates the positive influence of women's empowerment and entrepreneurial orientation on the business performance.

$\mathrm{H}_{6}$ : The business network mediates the positive influence of women's empowerment and entrepreneurial orientation on subjective well-being.

$\mathrm{H}_{7}$ : Business performance mediates the positive influence of women's empowerment, entrepreneurial orientation, and business networks on subjective well-being.

\section{Method}

The research design used is a quantitative research design and uses structural equation modeling analysis. SEM is an analytical method used for multiple variance (multivariate). Furthermore, variance or component-based SEM will be used, namely the Partial Least Square (PLS) method as an alternative to covariance-based SEM. This research was conducted on businesses engaged in the weaving industry in Bali Province. SMEs was chosen as the object of research since it is able to absorb a relatively large workforce and is one of the mainstay sectors of the community in Bali Province. The selection of research locations was conducted purposively by considering the existence of weaving industrial centers, entrepreneurial activities, and economic development in the relevant regency. Women's empowerment (X1) was reflected by three indicators: critical awareness (X1.1), access to resources (X1.2), and efforts to improve welfare (X1.3). Entrepreneurial orientation variables (X2): innovative (X2.1), taking risks (X2.2), and proactive (X2.3). Bricolage latent variables (X3): resource maximization (X3.1), opportunity exploration (X3.2), improvisation (X3.3). The business network variable (X4) is reflected by three latent sub-variables: the buyer's network (X4.1), product marketing (X4.2), raw material suppliers (X4.3). Business performance variable (Y1): Productivity (Y1.1); (2) Timeliness (cycle time) (Y1.2); cost and quality (Y1.3). Variables of subjective wellbeing (Y2): life satisfaction (Y2.1), optimism (Y2.2), harmonious social relations (Tri Hita Karana) (Y2.3). The approach used is construct validity by correlating the score of each item with the total score, using Pearson's Correlation Product Moment. Reliability measurement can be done using the Cronbach Alpha $(\alpha)$ technique. The criteria for an instrument is reliable if the reliability coefficient (rxy) Cronbach Alpha $>0.60$ (Ghozali, 2011). Determination of samples number selected using non-probability sampling. The sampling was 113 women weaving business owners. Primary data are obtained directly conducted by observation, interviews and distributing questionnaires to respondents. This study uses an instrument in the form of a questionnaire. The type of scale uses an ordinal scale. Each item in the questionnaire with each different value, namely: 
Score 1 = Strongly Disagree; Score 2 = Disagree; Score 3 = Neutral; Score 4 = Agree; Score $5=$ Strongly Agree. Structural equations in the inner model can be formulated:

$\begin{array}{ll}\mathrm{X}_{4} & =\beta_{1} \mathrm{X}_{1}+\beta_{2} \mathrm{X}_{2}+\varepsilon_{1} \\ \mathrm{Y}_{1} & =\beta_{3} \mathrm{X}_{1}+\beta_{4} \mathrm{X}_{2}+\beta_{5} \mathrm{X}_{3}+\beta_{6} \mathrm{X}_{4}+\beta_{7} \mathrm{X}_{1} \mathrm{X}_{3}+\varepsilon_{2} \\ \mathrm{Y}_{2} & =\beta_{8} \mathrm{X}_{1}+\beta_{9} \mathrm{X}_{2}+\beta_{10} \mathrm{X}_{4}+\beta_{11} \mathrm{Y}_{1}+\varepsilon_{3}\end{array}$

where:

$$
\begin{aligned}
& \mathrm{X}_{1}=\text { Woman Empowerment } \\
& \mathrm{X}_{2}=\text { Bricolage } \\
& \mathrm{X}_{3}=\text { Entrepreneurial orientation } \\
& \mathrm{X}_{4}=\text { Business Network }
\end{aligned}
$$

$\mathrm{Y}_{1}=$ Business Performance

$\mathrm{Y}_{2}=$ Subjective Wellbeing

$\beta_{1}, \beta_{2}, \beta_{3}, \beta_{4}, \beta_{5}, \beta_{6}=$ path coefficient

$\varepsilon_{1}, \varepsilon_{2}=$ inner residual

\section{Analysis and Results}

In general, weaving businesses in Bali Province are mostly carried out by women who are aged 40 years and over (a group that has been established in life and business experience), if a total of 48.67 percent, while young workers (under 40 years) quite a bit that is only 9.73 percent who want to work as entrepreneurs in the weaving industry. This condition is caused the weaving industry is a type of business that requires strong commitment, especially in the preservation of culture and business perseverance. The age group above 60 years old, there are still many who are involved as business people who diligently and faithfully maintain and preserve local wisdom in weaving business activities in Bali Province. Based on partial least square data processing, overall a full model of the relationship of indicators with their constructs, and the relationships between constructs. Based on research results it can be stated that all instruments or statement items used are valid. This is indicated by the significance of 0,000 . Regarding the correlation score of each instrument with the total score of the instrument group is between 0.751 and 0.962 . All of them had significance of less than 0.05 . Based on statistical results shows that all the Cronbach's Alpha coefficients for the variables of women's empowerment, entrepreneurial orientation, bricolage, business networks, business performance, and subjective well-being that have values above 0.50 , with the smallest range of 0.761 to 0.895. This means that all questionnaires as research instruments are reliable to measure the variables. Based on the results of partial least square data processing, overall a full model of the relationship of indicators with their constructs, and the relationships between constructs are shown in Fig. 1.

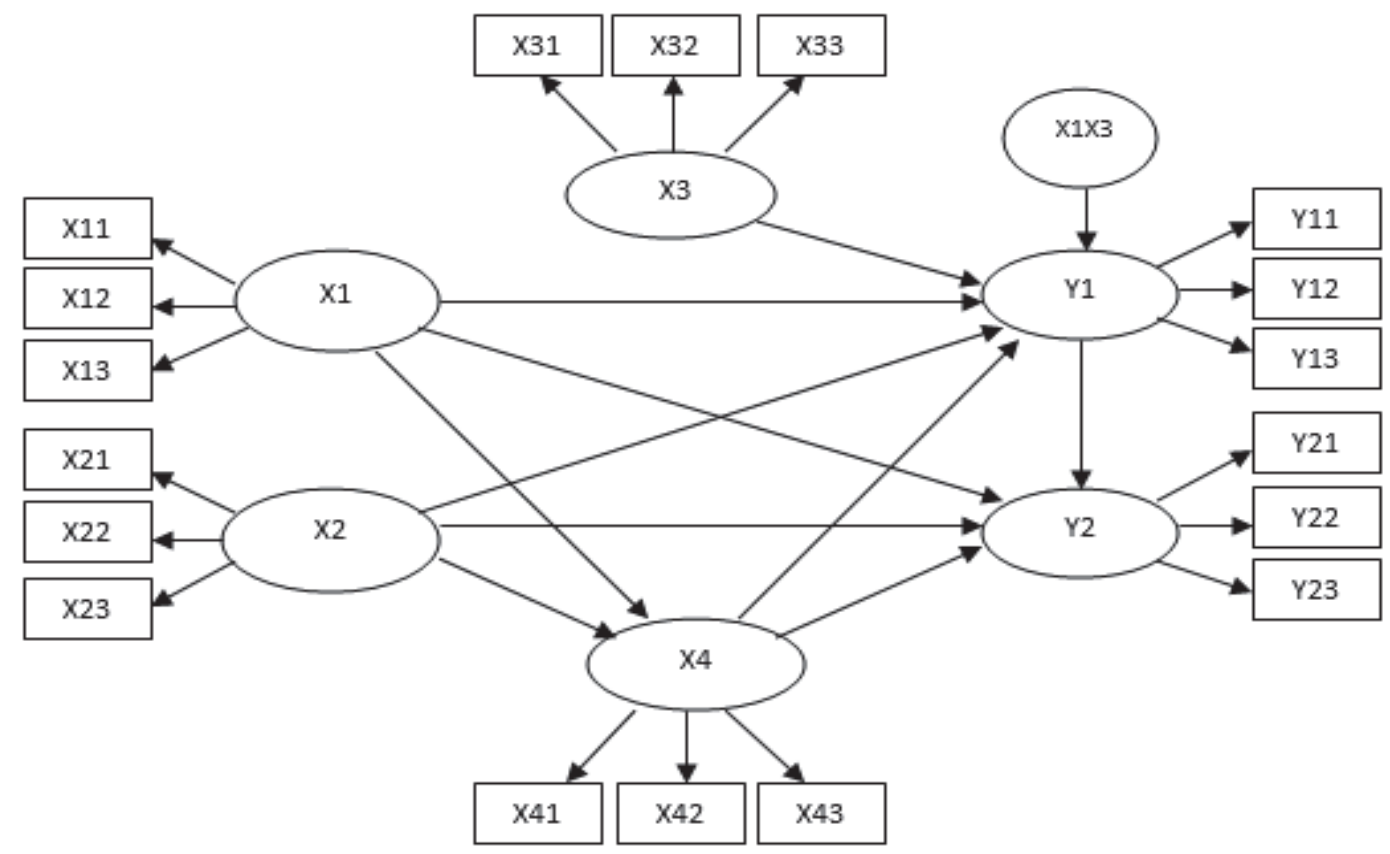

Fig. 1. Full Structural Model

According to the results of partial least square, all indicators for all constructs have a loading factor (original sample) close to or more than 0.50 , with a probability or significance level of less than 0.05 . Thus, it can be stated that all indicators on the variables (1) women's empowerment, (2) entrepreneurial orientation, (3) bricolage, (4) business networks, and (5) business performance, (6) subjective well-being, are proven valid forming their respective constructs-mind. Based on Fig. 1, it shows 
that the cross loading $X_{1.1}$ value of 0.794 in the Women Empowerment construct is higher than the cross loading value in the other constructs, which is 0.349 in the Entrepreneurship Orientation construct; 0.340 in the Bricolage construct; 0,498 in the Business Network construct; 0.398 on the construct of Business Performance and 0.462 on the construct of Subjective Welfare. All indicators meet discriminant validity in the Cross-loading test. This means that all indicators deserve to be included in further analysis.

Table 1

Cronbach's Alpha, Composite Reliability, Average Variance Extracted

\begin{tabular}{lccc}
\hline & Cronbach's Alpha & $\begin{array}{c}\text { Composite Relia- } \\
\text { bility }\end{array}$ & $\begin{array}{c}\text { Average Variance Ex- } \\
\text { tracted }\end{array}$ \\
\hline $\mathbf{X}_{\mathbf{1}}$ (Woman Empowerment) & & 0.878 & 0.705 \\
$\mathbf{X}_{\mathbf{1}} \mathbf{X}_{\mathbf{3}}$ (Moderating) & 0.790 & 0.913 & 0.543 \\
$\mathbf{X}_{\mathbf{2}}$ (Business Orientation) & 0.901 & 0.878 & 0.707 \\
$\mathbf{X}_{\mathbf{3}}$ (Bricolage) & 0.794 & 0.943 & 0.846 \\
$\mathbf{X}_{\mathbf{4}}$ (Business Network) & 0.909 & 0.854 & 0.661 \\
$\mathbf{Y}_{\mathbf{1}}$ (Business Performance) & 0.743 & 0.814 & 0.595 \\
$\mathbf{Y}_{\mathbf{2}}$ (Subjective Well-being) & 0.660 & 0.871 & 0.693 \\
\hline
\end{tabular}

Based on Table 1, the R-square value between 0.67-1.00 indicates that the model is good, while the R-square range between 0.34-0.66 indicates the structural model and if the R-square is between 0.33 and below indicates the model is classified as weak.

Table 2

R-Square Score

\begin{tabular}{llll}
\hline Latent Variable & R-Square & Adjusted R-Square & Information \\
\hline Business Network $\left(\mathrm{X}_{4}\right)$ & 0.530 & 0.521 & Moderate \\
Business Performance $\left(\mathrm{Y}_{1}\right)$ & 0.584 & 0.562 & Moderate \\
Subjective Well-being $\left(\mathrm{Y}_{2}\right)$ & 0.735 & 0.724 & Strong \\
\hline
\end{tabular}

Based on $\mathrm{R}^{2}$ in Table 2 it can be calculated $\mathrm{Q}^{2}$ or Stone Geiser Q-square test, namely:

$$
\mathrm{Q}^{2}=1-\left(\left(1-\mathrm{R}^{2}{ }_{1}\right)\left(1-\mathrm{R}_{2}{ }_{2}\right)=0.88\right.
$$

$\mathrm{Q}^{2}$ value of 0.88 means that 88 percent of the variation of the well-being of weaving craft SMEs in Bali Province can be explained by variations in women's empowerment, bricolage, entrepreneurial orientation, business performance and more or less the rest 12 percent is explained by other variables outside the study. To analyze the direct effect of a construct on other constructs as hypothesized, it is presented in Table 3.

Table 3

Path Coefficient or Variable Direct Effect

\begin{tabular}{|c|c|c|c|c|}
\hline Variable Correlation & Original sample & Standard deviation & $\mathrm{t}-$ Statistics & P-value \\
\hline $\mathrm{X} 1 \rightarrow \mathrm{X} 4$ & 0.447 & 0.086 & 5.175 & $0.000^{*}$ \\
\hline $\mathrm{X} 2 \rightarrow \mathrm{X} 4$ & 0.429 & 0.070 & 6.160 & $0.000^{*}$ \\
\hline $\mathrm{X} 1 \rightarrow \mathrm{Y} 1$ & 0.142 & 0.098 & 1.447 & $0.149 * *$ \\
\hline $\mathrm{X} 2 \rightarrow \mathrm{Y} 1$ & 0.240 & 0.091 & 2.633 & $0.009 *$ \\
\hline $\mathrm{X} 3 \rightarrow \mathrm{Y} 1$ & 0.242 & 0.101 & 2.403 & $0.017^{*}$ \\
\hline $\mathrm{X} 4 \rightarrow \mathrm{Y} 1$ & 0.254 & 0.092 & 2.766 & $0.006^{*}$ \\
\hline $\mathrm{X} 1 \rightarrow \mathrm{Y} 2$ & 0.172 & 0.070 & 2.449 & $0.015^{*}$ \\
\hline $\mathrm{X} 2 \rightarrow \mathrm{Y} 2$ & 0.195 & 0.081 & 2.423 & $0.016^{*}$ \\
\hline $\mathrm{X} 4 \rightarrow \mathrm{Y} 2$ & 0.312 & 0.083 & 3.773 & $0.000^{*}$ \\
\hline $\mathrm{Y} 1 \rightarrow \mathrm{Y} 2$ & 0.348 & 0.088 & 3.954 & $0.000 *$ \\
\hline $\mathrm{X} 1 \mathrm{X} 3 \rightarrow \mathrm{Y} 1$ & 0.239 & 0.109 & 2.192 & $0.029 *$ \\
\hline
\end{tabular}

* significant at $\mathrm{p}$-value $<0,05$

** insignificant at p-value $>0,05$

Based on Table 3 can be explained that greater business performance is influenced by business networks compared to women's empowerment, entrepreneurial orientation, and bricolage with a coefficient of 0.254 compared to $0.142 ; 0.240$ and 0.242 . Furthermore, subjective well-being is most influenced by business performance, which has a stronger influence, with a coefficient of 0.348 compared to women's empowerment, entrepreneurial orientation, and business networks with a comparison coefficient of $0.172 ; 0,195$ and 0,312 . 
Table 4

Indirect Effects of Exogenous Variables on Endogenous Variables through Mediation Variables

\begin{tabular}{lccccc}
\hline Variable Correlation & Mediating Variable & Original & Standard & t- Statistics & P-Value \\
\hline $\mathrm{X} 1 \rightarrow$ Y1 & $\mathrm{X} 4$ & 0,114 & 0,048 & 2,378 & $0,018^{*}$ \\
$\mathrm{X} 2 \rightarrow$ Y1 & $\mathrm{X} 4$ & 0,109 & 0,045 & 2,440 & $0,015^{*}$ \\
$\mathrm{X} 1 \rightarrow$ Y2 & $\mathrm{Y} 1$ & 0,228 & 0,061 & 3,747 & $0,000^{*}$ \\
$\mathrm{X} 2 \rightarrow$ Y2 & Y1 & 0,255 & 0,053 & 4,783 & $0,000^{*}$ \\
$\mathrm{X} 3 \rightarrow$ Y2 & $\mathrm{Y} 1$ & 0,084 & 0,043 & 1,953 & $0,051^{*}$ \\
$\mathrm{X} 4 \rightarrow$ Y2 & $\mathrm{Y} 1$ & 0,088 & 0,041 & 2,170 & $0,030^{*}$ \\
$\mathrm{X} 1 \mathrm{X} 3 \rightarrow$ Y2 & $\mathrm{Y} 1$ & 0,083 & 0,043 & 1,924 & $0,055^{*}$ \\
\hline
\end{tabular}

* significant at p-value $<0,05$

Based on the information in Table 4, it can be explained the indirect effect of an exogenous variable on endogenous variables through mediating variables. Women's empowerment and entrepreneurial orientation influence business performance mediated by business networks. The statement revealed that with increasing intensity, the quality of women's empowerment and entrepreneurial orientation caused business networks in the weaving industry to increase, business performance also increased. Furthermore, the positive influence of women's empowerment and entrepreneurial orientation mediated by the business network causes subjective well-being to increase. The analysis shows that the business performance regression coefficient mediates the effect of women's empowerment, entrepreneurial orientation, and business networks on subjective well-being.

\section{Discussion}

\subsection{The Direct Effect of Women's Empowerment and Entrepreneurship Orientation on Business Networks}

The results of research and data analysis show that women's empowerment and entrepreneurial orientation directly have a significant effect on business networks. Empowerment is the ability to manage a value that exists in human resources both in groups and individually that aims to be able to be independent in accordance with the wishes. Empowerment is carried out through programs organized by the government, private sector and non-governmental organizations or SMEs aimed at increasing the ability, skills, and expertise of weaving SMEs to increase productivity and welfare. Women's empowerment is important for better social and economic development in Bali Province. During this weaving business has received coaching assistance from the Regional Government, Dekranasda (Regional National Crafts Council), SOEs, and Citta Tenun Indonesia. The assistance is in the form of training, capital, and promotion. Now the participation of Balinese women in economic development has increased, although not yet significantly. At present the level of participation of Balinese women in terms of economic empowerment has increased, as seen from the income figures of Balinese women who reach 37 percent where the figure is above the national average. In the opinion of most respondents, the weaving business which is occupied gives enough income to meet the family economy. Especially the support they get through the training they get. The existence of weaving handicraft SMEs managed by women certainly has an impact on the surrounding environment. This support is carried out by forming a business community network to get new ideas that are useful in business development, especially in terms of design, coloring techniques, production and marketing techniques so as to increase the amount of productivity, number of orders, and expand the buyer network (Ofoegbu et al., 2013; Choi \& Lim, 2017). Support from the business community network results in facilitating the acquisition of new market opportunities and expanding supply chains, the ease of obtaining technology for production and also the ease of utilizing technology in marketing. SMEs must continue to innovate to be able to survive in a changing environment. In today's business environment, organizations need to consider innovation as a key factor in organizational products and processes to survive dynamic environments and technological change (Vidal et al., 2006; Baron \& Tang, 2011).

5.2 The Direct Effect of Women's Empowerment, Entrepreneurship Orientation, Business Networks and Bricolage on Business Performance

The research results and data analysis indicate that entrepreneurial orientation, bricolage and business networks have a significant effect on business performance. Increasing intensity and quality of entrepreneurial orientation, bricolage and business networks will also increase business performance in weaving industry players in the province of Bali. Women's empowerment has a insignificant effect on business performance, which means that increasing the intensity and quality of women's empowerment has not been able to optimally improve business performance in the weaving industry. Empowerment has not been able to optimally improve the skills and expertise of business actors so that they are more productive in using the factors of production. Other empowerment benefits should be to improve product quality through increased productivity and efficiency and market-oriented competitiveness. Women's empowerment will not achieve optimal results in achieving business performance improvement amid limited resources, other efforts need to be made to strengthen the role of empowerment in achieving business performance improvement. Whereas women's empowerment has a noble aim to increase added value to all members or individuals, but the obstacle that often arises is the limited resources, namely updated information. However, various efforts have been made so that the empowerment of women, especially entrepreneurs in the weaving industry, can improve their business performance. Even though the actual income earned by women weaving craftsmen is not yet sufficient to improve 
their welfare, because there are still constraints they experience, namely in access to raw materials and labor. Whereas easy access to raw materials can improve business performance, especially entrepreneur skills because with easy access to raw materials will cause SMEs to have many choices for obtaining cheap raw materials (Sila, 2007; Edwards-Schachter et al., 2015). For weaving craftsmen, generally access to raw materials is a problem, because there are some craftsmen who get it through collectors. This is also the case with labor constraints caused by the absence of regeneration or the younger generation who continue their business or nearly 41 percent of weavers aged over 50 years. Through various efforts made by these women handicraft entrepreneurs and increasing synergy with the government, various obstacles have been sought to be overcome. Women's empowerment in the context of improving business performance is not in line with research conducted by Buttner \& Moore (1997); Robb \& Coleman (2009); Axtell (2001), where the success of empowering women in improving company performance will be better if it is associated with an increase in company size, then proxied by increasing sales. Assistance and guidance is also expected to strengthen the economic structure, strengthen and preserve local culture. In fact, weaving is not just a legacy down, but has become a vein for the survival of the craftsmen. Some of the weaving craft production is made based on orders from consumers and overall, the production process is quite smooth although a small portion is still experiencing fluctuations in production. In addition, weaving industry entrepreneurs also continue to develop innovations in designs that are produced so that they have high selling power and are able to compete in both the domestic and export markets. This condition shows that weaving handicraft SMEs in Bali Province is very dependent on the availability of raw materials from outside. This condition has made production costs to increase, because weaving industry entrepreneurs must allocate transportation costs that are not small to bring in raw materials from outside the region, not to mention the legality constraints of raw materials. Some policies are needed that can ease the burden on SMEs, especially related to the availability of raw materials. However, the empowerment activities undertaken have not optimally contributed significantly to improving the performance of the SME handicraft business. This is due to the empowerment activities that have not been fully able to solve the problems experienced by craftsmen of weaving related to access to economic resources in the form of raw materials and labor. Limited raw materials and labor cause productivity to not increase from time to time. This has caused some craftsmen to consider the business being run only as a side business. Even the empowerment activities undertaken by the Government in cooperation with SOEs have not been felt optimally by craftsmen and tend to be monotonous. Whereas the training activities carried out are expected to be able to improve HR competencies especially in the fulfillment of work experience and skills (Ismaila et al., 2013).

In connection with these risks which are not only faced by weaving entrepreneurs in terms of production or marketing, but also the claiming of motives by irresponsible elements. One of them is found a case of imitation of motifs on the motif of weaving crafts in Tenganan Pagringsingan Village. In addition to Tenganan, there are many cases of imitation of woven handicraft motifs, such as those that occur in woven fabrics produced by craftsmen in Gelgel Village, Klungkung District. Departing from these problems, the regulation of Copyright is absolutely necessary in order to protect Balinese weaving motifs. The motives of weaving crafts have legal power that can strengthen the existence of Balinese weaving craft motifs. During this time, craftsmen cannot take an action in handling cases of imitation of existing woven craft motifs. That was caused by the absence of Copyright arrangements for weaving craft motifs in the local village. Based on the findings of researchers in the field that the regulation of copyrights to existing woven craft motifs, such as in Gelgel Village, cannot yet be fully carried out, it is caused by several factors that cause the management of Copyrights for weaving crafts in Gelgel Village cannot be done, namely: first, in terms of history or history of typical Gelgel weaving craft motifs both in terms of time and its creator is not known with certainty. In addition, this fabric motif has similarities with woven fabric motifs in Karangasem and other villages. Support for the development of weaving SMEs is also shown by sales cooperation with villages and agencies, and also depends on product demand and supply. Kale et al. (2002) argue that with network capabilities, it shows the ability to coordinate companies in cooperative activities, obtain market knowledge or information from outside (Das \& Teng, 2000) and fast internal communication (Sivadas \& Dwyer, 2000). This can facilitate the entrepreneurship process of women craftsmen, especially business networks on performance.

\subsection{The Direct Effect of Women's Empowerment, Entrepreneurial Orientation, Business Networks and Business Performance on Subjective Well-being}

The research results and data analysis show that women's empowerment, entrepreneurial orientation, business networks, and business performance have a significant impact on subjective well-being, which means increasing intensity and quality of women's empowerment, entrepreneurial orientation, networking business, and business performance also increases the subjective well-being. Related to work involvement, research that consistently shows a positive relationship between women's empowerment and subjective well-being (Halbesleben \& Wheeler, 2008; Xanthopoulou et al. (2009). Other research (Dej, 2011) found a positive relationship between work engagement and subjective entrepreneurial success (Dijkhuizen, 2015) and business growth and subjective business performance. Another aspect that influences whether happy workers are productive workers' gain support in previous studies is the research time frame (Gorgievski et al., 2014). The results of this study are not in line with research by Hoop et al. (2014). The results of his research found that the membership of women's self-help groups had a positive impact on women's autonomy, but on average the membership of the self-help groups did not affect subjective well-being. In addition, for members who live in communities with relatively conservative gender norms, subjective wellbeing will be much lower. 
Entrepreneurial research generally emphasizes outcomes such as growth and performance. However, people pursue entrepreneurship for very personal and special reasons. Therefore, the relationship between entrepreneurship and welfare is very important. Entrepreneurial well-being as an experience of satisfaction, positive influences, negative influences, and psychological functions in relation to developing, growing, and running an entrepreneurial business (Ryff \& Singer, 1998; Ryan \& Deci, 2000; Diener et al., 2010; Seligman, 2012). Entrepreneurship often drives positive changes in society that provide breakthroughs in commercial or social innovation that contribute to prosperity. Entrepreneurship is also a potential source of personal development, growth and well-being (Shir, 2015; Stephan, 2018). Subjective well-being is not only seen from the economic side (income) but also includes other subjective well-being such as civil liberties, freedom from crime, a clean environment and the condition of a physically and mentally healthy population (The Organisation for Economic Co-operation and Development (OECD), 2013). This requires entrepreneurial competence or entrepreneurial culture. The influence of these three efforts in improving people's subjective social welfare is marked by an increase in real income, level of education, health and a sense of security and comfort (several indicators of subjective well-being). Entrepreneurship can offer freedom from restrictions and unsatisfactory work conditions (Al-Dajani et al., 2015; Rindova et al., 2009), and provide autonomy to pursue passion and engage in meaningful work (Baron, 2016). On the other hand, entrepreneurship can be very stressful because of the high level of uncertainty, change and risk, and various responsibilities that employers must face when working long hours (Uy et al., 2013). These challenging and stressful conditions, combined with high levels of entrepreneurship in business, can affect the subjective well-being of entrepreneurs (Baron et al., 2016). The ability to cope with stress and maintain high subjective well-being, however, is important for the functioning of effective entrepreneurs who can influence entrepreneurial performance (Haynie \& Shepherd, 2009). According to Conservation of Resources theory (COR), individuals seek to accumulate, maintain, and protect resources. Resources are defined as functional objects, conditions, energy or personal contributions that have an objective value or facility for achieving a valued goal. Thus, business networks represent contextual resources by providing entrepreneurs with access to social support, thereby increasing the psychological resources of entrepreneurs, and increasing subjective well-being. Through increased business productivity, timeliness in completing work or production, and certain costs incurred in order to improve quality, ultimately can increase life satisfaction, optimism, and harmonious social relations. Although the increase in productivity is not too high, most craftsmen always get orders, and even have regular customers who buy their products. The limited workforce does not hamper the performance of the craftsmen to complete their orders on time. The use of production costs is also adjusted by using natural dyes as an alternative while maintaining product quality. So, the increase in performance felt by the craftsmen ultimately leads to provide satisfaction for the craftsmen.

\subsection{Bricolage Moderates the Effect of Women's Empowerment on Business Performance}

The research results and data analysis show that women's empowerment directly affects the business performance that is moderated by bricolage. This means that the increasing intensity and quality of women's empowerment causes business performance to increase, which is strengthened by the role of bricolage. Empowering women by strengthening synergy carried out by SME owners of weaving industries and the government can help expedite or at least not inhibit the acquisition of raw materials, production processes, marketing and also support business processes (Obaji \& Olugu, 2014). Bricolage is very important for women weaving business who are trying to improve company performance. Women in resource-poor environments can provide unique services by recombining elements that they have for new purposes (Baker \& Nelson, 2005). This study is in line with Senyard et al. (2014) who found that companies involved in bricolage have a positive and significant impact on new product innovation under resource constraints, thus, bricolage plays an important role towards innovation with limited resources. Furthermore, Cunha et al. (2014) found that creative approaches to resource scarcity can contribute to the enrichment of knowledge about entrepreneurship. A higher level of empowerment is positively related to company revenue, accompanied by a higher level of bricolage that will further strengthen the relationship. To be involved in successful bricolage, an individual must determine his own destiny and be independent in his decision (Cunha, 2005); if not, without autonomy, women will be less empowered to use the most valuable alternatives (Bojica et al., 2015). Furthermore, to be involved in a successful bricolage, a woman must also be confident in her ability as an entrepreneur. This study is in line with Hmieleski \& Baron (2008) found that bricolage is negatively associated with performance at low levels of self-efficacy of entrepreneurs. Digan et al. (2019) states that empowerment of women's entrepreneurship is positively related to business performance (corporate income). The benefits of empowerment can be further enhanced for women entrepreneurs who manage resource constraints through bricolage, and meet entrepreneurial challenges through psychological capital.

\subsection{Business Networks Mediate the Effects of Women's Empowerment and Entrepreneurship Orientation on Business Perfor- mance}

The data analysis indicate that women's empowerment indirectly influences business performance through business networks. The indirect influence of women's empowerment and entrepreneurial orientation on business performance, means that women's empowerment and entrepreneurial orientation that have a significant and positive effect on business performance cannot be separated from the role of business networks. The results of this study indicate that the strengthening of women's empowerment and entrepreneurial orientation of weaving businesses in the Province of Bali will improve business networks, so that they can improve business performance. A network, is an alternative to using internal resources (Dollinger, 1999). Networking is a variable that is considered important for all types of companies, especially with regard to the fact that an increasingly competitive economic environment. Networks are becoming increasingly important because they make it easier for companies 
to access information, resources, markets and technology (Gulati et al., 2000). Information and social networking are considered important for the formation of companies and for the success and sustainability of the company (Malecki, 1997). Innovation can also be realized through the role of entrepreneurial orientation in each activity to achieve company goals with the support of business networks. Business networks enable women entrepreneurs to weave separately to find new ideas that are useful in making innovative breakthroughs. This research is in line with Wiklund (1999) which states that a higher entrepreneurial orientation can improve a company's ability to market its products towards better business performance. Research conducted by Nuvriasari et al. (2015) shows a significant influence between entrepreneurial orientation on company performance. Entrepreneurship often drives positive changes in society that provide breakthroughs in commercial or social innovation that contribute to prosperity. Entrepreneurship is also a potential source of personal development, growth and well-being (Shir, 2015); Stephan (2018). The success of a business requires the ability of entrepreneurial orientation in every individual in the company. Entrepreneurial orientation which consists of autonomy, taking receipts, proactively will affect innovation in a company. SMEs must continue to innovate to be able to survive in a changing environment. In today's business environment, organizations need to consider innovation as a key key factor in organizational products and processes to survive dynamic environments and technological change.

\subsection{The Business Network Mediates the Effect of Women's Empowerment and Entrepreneurship Orientation on Subjective Well-being}

The results show that women's empowerment and entrepreneurial orientation indirectly affect subjective well-being mediated by business networks. This means that the increase in the intensity and quality of women's empowerment and entrepreneurial orientation causes business networks to increase, subsequently with increasing business networks, subjective well-being increases. The indirect influence of women's empowerment and entrepreneurial orientation on subjective well-being, means that women's empowerment and entrepreneurial orientation that have a significant and positive effect on subjective well-being cannot be separated from the role of business networks. Welfare improvement efforts are always carried out by women entrepreneurs in weaving handicrafts in terms of food, income, and health. Workforce assistance activities are carried out on an incentive basis in addition to improving skills as well as efforts to ensure social security and health (Mousiolis \& Bourletidis, 2015). Empowering women to improve business performance can be strengthened through the support of an entrepreneurial orientation that enables women entrepreneurs to enhance new ideas that are beneficial through the business community that is formed through social relations. According to Neve (2013) the process of balancing steps in socioeconomic progress as a measure of subjective well-being can be done through increasing entrepreneurial competence and economic capacity (performance). Given the tangible benefits of individual social relations to the level of subjective well-being, it is increasingly urgent to act effectively that enables everyone to develop and place entrepreneurial activities as their main activities. The potential of entrepreneurial orientation and its impact on the subjective well-being (life satisfaction) of women weaving craftsmen depends on the role of the business network as a driver or pioneer for the ability of organizations to take advantage of business opportunities (through business networks) and innovation (getting useful ideas through buyer networks) (Poudel, 2012). The entrepreneurial orientation is the key to organizational success and achieving profitability and prosperity. Companies that adopt an entrepreneurial orientation will have better performance than those who do not adopt (Taylor, 2013). The entrepreneurial orientation is very important for increasing the competitive advantage of the weaving business. Companies must innovate to meet the needs of potential customers, engage in new exploration, support new ideas, test and simulate creatively. All of these are efforts in producing new products, services or technological processes, and changes in existing technologies and practices.

\subsection{Business Performance Mediates the Effects of Women's Empowerment, Entrepreneurship Orientation, and Business Net- works on Subjective Well-being}

The research results and data analysis indicate that women's empowerment, entrepreneurial orientation, and business networks indirectly affect subjective well-being through business performance. The relationship of women's empowerment effect on subjective well-being requires mediation that is able to drive women's empowerment of business actors through business performance (productivity, timeliness, cost and quality) to produce life satisfaction, optimism, and harmonious social relations. Women's empowerment is very important for better social and economic development, especially the empowerment of women in the weaving industry sector which has a great opportunity to provide adequate employment for Balinese women. In the opinion of the majority of respondents, the weaving business which is occupied gives enough income to meet the family's economy and provides sufficient income. Especially the support they get through the training they get. In fact, they are active as a driving force in it through the women's weaving crafts business groups in their area. Woven cloth, besides having cultural value, also has commercial value. Through woven cloth which is a traditional cloth as one of the riches of cultural heritage, it is not only seen in terms of techniques and various shades and types of fabric made, but it can be expressed in depth and implied various functions and meanings of fabric in people's lives, reflecting the beliefs, customs, ways of thinking, identity and identity of a cultured nation (as a concept of Tri Hita Karana). Until now the woven fabric which is a traditional cloth continues to be dug up and developed. This study further proves the relationship between psychological factors and women's entrepreneurial orientation which plays an important role in women's entrepreneurial orientation because the need to achieve power and affiliation is all reflected through psychological characteristics. If women entrepreneurs are ready to learn new techniques, they can implement new innovations because they are rarely afraid of failure. Psychologically 
they have the courage to face failure and remain in business, which is reflected in this research. The weaving industry business which is managed from generation to generation and contains the philosophy of Tri Hita Karana, was able to improve women's subjective well-being in sustainable economic development. Through business network strengthening, it is able to provide women entrepreneurs in the form of access to social support, so as to increase income and lead to an increase in psychological resources in the form of happiness, optimism, and satisfaction which are dimensions of subjective well-being.

\section{Implications for Theory and Practice}

The renewal of this research is to include bricolage in order to improve the performance of SME businesses, as well as subjective well-being which is measured using psychological aspects namely life satisfaction and harmonious social relationships (using the concept of Tri Hita Karana). In addition, this study simultaneously tested a variety of variables, both women's empowerment and entrepreneurial orientation in order to improve the subjective well-being of woven handicraft SMEs in Bali Province. Based on the results of research on women's empowerment has the smallest influence on business performance and subjective well-being when compared to other variables in the study, this condition is also supported by the statement of SMEs that there are fundamental problems related to access to raw materials, access to labor, and market access. Young weaving handicraft SMEs as well as young skilled craftsmen in the industry are very limited. There is a poor regeneration related to the sustainability of the weaving craft business and skilled labor that produces Balinese products as a form of local wisdom handed down from generation to generation. The study found that the variable of women's empowerment did not have a significant impact on business performance if tested directly, but the impact was significant if it was strengthened by the role of bricolage. Improving women's business performance in weaving crafts through strengthening the role of bricolage has proven to be able to support the local economy of the craftsmen. The strengthening is able to encourage community initiatives and provide motivation especially for women to carry out alternative economic activities as an effort to survive amid limited resources. The success of the role of women craftsmen weaving and managed independently or in groups with the help of various elements related to both the government, SOEs, and Dekranasda. The presence of women in which as a representative of the community acts as a subject not an object. In line with participatory economic goals, the position of women as one element of regional stakeholders will be the main driver in the wheels of economic activity in the region.

\section{References}

Al-Dajani, H., Carter, S., Shaw, E., \& Marlow, S. (2015). Entrepreneurship among the displaced and dispossessed: Exploring the limits of emancipatory entrepreneuring. British Journal of Management, 26(4), 713-730.

Axtell, R. L. (2001). Zipf Distribution of U . S . Firm Sizes. Science, 293(5536), 1818-1820.

Baker, T., \& Nelson, R. E. (2005). Bricolage creating something from nothing: Resource construction through entrepreneurial. Administrative Science Quarterly, 50, 329-366.

Baron, R. A., Franklin, R. J., \& Hmieleski, K. M. (2016). Why entrepreneurs often experience low, not high, levels of stress: The joint effects of selection and psychological capital. Journal of Management, 42(3), 742-768.

Baron, R., \& Tang, J. (2011). The role of entrepreneurs in firm-level innovation: Joint effects of positive affect, creativity, and environmental dynamism. Journal of Business Venturing, 26(1), 49-60.

Bojica, A. M., Fuentes-Fuentes, M. M., \& Istanbouli, A. (2015). Bricolage and growth strategies: Effects on the performance of Palestinian women-led firms. Journal of Developmental Entrepreneurship, 19(4), 1-42.

Bojica, A. M., Istanbouli, A., \& Fuentes-fuentes, M. D. M. (2015). Bricolage and growth strategies: Effects on the performance of Palestinian women-Led firms. Journal of Developmental Entrepreneurship, 19(4), 1-23.

Budiasih, I. G. A. N., \& Suardikha, I. M. S. (2017). Impact of tri hita karana culture on the use of accounting information systems and user satisfaction as the expression of information system success. Accounting and Finance Review, 2(3), 3845.

Buttner, E. H., \& Moore, D. P. (1997). Women's organizational exodus to entrepreneurship: Self-reported motivations and correlates with success. Journal of Small Business Management, 35(1).

Choi, Y. S., \& Lim, U. (2017). Contextual factors affecting the innovation performance of manufacturing SMEs in Korea: A structural equation modeling approach. Sustainability, 9(7), 1193.

Clifton, N., Keast, R. L., Pickernell, D., \& Senior, M. (2010). Network structure, knowledge governance, and firm performance : Evidence from innovation networks and SMEs in the UK. Growth and Change, 41(3), 337-373.

Cunha, O. M. G. Da. (2014). Unmapping knowledge: Connecting histories about haitians in Cuba. Social Anthropology, 22(1), 67-80.

Cunha, M. P. E. (2005). Bricolage in Organizations (No. 474). Lisbon.

Cunha, M. P. e, Rego, A., Oliveira, P., Rosado, P., \& Habib, N. (2014). Product innovation in resource-poor environments: Three research streams. Journal of Product Innovation Management, 31(2), 202-210.

Daft, R. L. (2010). New era of management (9th ed.). Mason, Ohio : South-Western: London : Cengage Learning.

Das, T. K., \& Teng, B.-S. (2000). A resource-based theory of strategic alliances. Journal of Management, 26(1), 31-61.

Dej, D. (2011). Exploring Entepreneur Success From A Work Psychology Perspective: The Development and Firstvalidation of A New Instrument. TU Dresden.

Diener, E., Heintzelman, S., Kushlev, K., Tay, L., Wirtz, D., Lutes, L. D., \& Oishi, S. (2017). Findings all psychologists should know from the new science on subjective well-being. Canadian Psychology, 58(2), 87-104. 
Diener, E., Wirtz, D., Tov, W., Kim-Prieto, C., Choi, D., Oishi, S., \& Biswas-Diener, R. (2010). New well-being measures: Short scales to assess flourishing and positive and negative feelings. Social Indicators Research, 97(2), $143-156$.

Digan, S. P., Sahi, G. K., Mantok, S., \& Patel, P. J. (2019). Women's perceived empowerment in entrepreneurial efforts: The role of bricolage and psychological capital. Journal of Small Business Management, 57(1), 206-229.

Dijkhuizen, J. (2015). Entrepreneurship, Easier Said than Done: A Study On Success and Well-Being Among Entrepreneurs in the Netherlands. Ridderkerk.

Dollinger, M. J. (1999). Entrepreneurship : Strategies and Resources (2nd ed.). Upper Saddle River, N.J.: Upper Saddle River, N.J. : Prentice Hall.

Domenico, M. L. Di, Haugh, H., \& Tracey, P. (2010). Social bricolage : Theorizing social value creation in social enterprises. Entrepreneurship Theory and Practice, 36(4), 681-703.

Gede, P. I. (2010). Tri Hita Karana-The Local Wisdom of the Balinese in Managing Development. Trends and Issues in Global Tourism, 139-150.

Ghozali, I. (2011). Aplikasi Analisis Multivariate Dengan Program IBM SPSS 19 (5th ed.). Semarang: Badan Penerbitan Universitas Diponegoro.

Gorgievski, M. J., Bakker, A. B., \& Moriano, J. A. (2014). Relating Work Engagement and Workaholism to Entrepreneurial Performance. Journal of Managerial Psychology, 29(2), forthcoming.

Gronum, S., Verreynne, M., \& Kastelle, T. (2012). The role of networks in small and medium-sized enterprise innovation and firm performance. Journal of Small Business Management, 50(2), 257-282.

Gulati, R., Nohria, N., \& Zaheer, A. (2000). Strategic Networks. Strategic Management Journal, 21(3), $203-215$.

Halbesleben, J. R. B., \& Wheeler, A. R. (2008). The relative roles of engagement and embeddedness in predicting job performance and intention to leave. Work and Stress, 22(3), 242-256.

Haynie, M., \& Shepherd, D. A. (2009). A measure of adaptive cognition for entrepreneurship research. Entrepreneurship Theory and Practice, 33(3), 695-714.

Hmieleski, K. M., \& Baron, R. A. (2008). When Does Entrepreneurial Self-Efficacy Enhance Versus Reduce Firm Performance? Strategic Entrepreneurship Journal, 2(1), 57-72.

Holm, M. R., Lugosi, P., Croes, R. R., \& Torres, E. N. (2017). Risk-tourism, risk-taking and subjective well-being: A review and synthesis. Tourism Management, 63, 115-122.

Hoop, T. De, Linssen, R., Kempen, L. van, \& Eerdewijk, A. Van. (2014). Women's autonomy and subjective well-being: How gender norms shape the impact of self-help groups in Odisha, India. Feminist Economics, 20(3), $103-135$.

Hubeis, A. V. S. (2010). Pemberdayaan perempuan dari masa ke masa. Bogor: Institut Pertanian Bogor Press.

Indarti, N., \& Postma, T. J. B. M. (2013). Effect of networks on product innovation: Empirical evidence from Indonesian SMEs. Journal of Innovation Management, 1(2), 140-158.

Ismaila, M. D., Khairy, A., Domila, A., \& Isa, A. M. (2013). Managerial competence, relationship quality and competitive advantage among SME exporters. In The 5th Indonesia International Conference on Innovation, Entrepreneurship, and Small Business (IICIES).

Kale, P., Singh, H., \& Dyer, J. H. (2002). Alliance Capability, Stock Market Response, and Long Term Alliance Success: The Role of the Alliance Function. Strategic Management Journal, 23(8), 747-767. https://doi.org/10.1002/smj.248

Knoop, H. H., \& Delle, F. A. (2013). Well-Being and Cultures: Perspective from Positive Psychology. New York: USA: Springer Science, Business Media.

Linna, P. (2013). Bricolage as a means of innovating in a resource-scarce environment: A study of innovator-entrepreneurs at the BOP. Journal of Developmental Entrepreneuship, 18(3), 1-23.

Malecki, E. J. (1997). Technology and Economic Development: The Dynamics of Local, Regional, and National Change.

Miller, D. (2011). Miller (1983) Revisited:A Reflection on EO Research and Some Suggestions for the Future. Entrepreneurship Theory and Practice, 35(5), 873-894.

Mousiolis, D. T., \& Bourletidis, K. (2015). The Corporate Identity through the CSR's Paths. In Procedia - Social and Behavioral Sciences (pp. 511-514). Madrid, Spain: Science Direct, Elsevier.

Najib, M., \& Kiminami, A. (2011). Innovation, cooperation and business performance. Journal of Agribusiness in Developing and Emerging Economies, 1(1), 75-96.

Neve, J.-E. De, Diener, E., Tay, L., \& Xuereb, C. (2013). The Objective Benefits of Subjective Well-Being (CEP Discussion Papers No. 1236).

Nuvriasari, A., Wicaksono, G., \& Sumiyarsih. (2015). Peran Orientasi Pasar, Orientasi Kewirausahaan dan Strategi Bersaing terhadap Peningkatan Kinerja UKM. Ekuitas: Jurnal Ekonomi Dan Keuangan, 19(2), 241-259.

Obaji, N. O., \& Olugu, M. U. (2014). The role of government policy in entrepreneurship development. Science Journal of Business and Management, 2(4), 109-115.

Ofoegbu, E. O., Akanbi, P. A., \& Joseph, A. I. (2013). Effects of contextual factors on the performance of small and medium scale enterprises in Nigeria: A case study of Ilorin Metropolis. Advances in Management \& Applied Economics, 3(1), 95114.

Poudel, K. P., Carter, R., \& Lonial, S. (2012). The process aspect of entrepreneurial orientation-performance relationship: Uncovering the mediating roles of technological capabilities, innovation and firm growth. Frontiers of Entrepreneurship Research, 32(12), 1-15.

Rindova, V., Barry, D., \& Ketchen, D. J. (2009). Entrepreneuring as emancipation. Academy of Management Review, 34(3), 477-491. 
Robb, A., \& Coleman, S. (2009). The impact of financial capital on business performance: A comparison of women- and men-owned firms, 1-28.

Ryan, R. M., \& Deci, E. L. (2000). Self-determination theory and the facilitation of intrinsic motivation, social development, and well-being. American Psychologist, 55(1), 68-78.

Ryff, C. D., \& Singer, B. (1998). The contours of positive human health. An International Journal for the Advancement of Psychological Theory, 9(1), 1-28.

Seligman, M. E. P. (2012). Flourish: A Visionary New Understanding of Happiness and Well-Being. Pennsylvania: Simon and Schuster.

Senyard, J., Baker, T., Steffens, P., \& Davidsson, P. (2014). Bricolage as a path to innovativeness for resource-constrained new firms. The Journal of Innovation Management, 31(2), 211-230.

Shir, N. (2015). Entrepreneurial Well-Being: The Payoff Structure of Business Creation.

Siedlecki, K. L., Salthouse, T. A., Oishi, S., \& Jeswani, S. (2013). The relationship between social support and subjective well-being across age. Social Indicators Research, 117(2), 561-576.

Sivadas, E., \& Dwyer, R. F. (2000). An examination of organizational factors influencing new product success in internal and alliance-based processes. Journal of Marketing, 64(1), 31-49.

Stephan, U. (2018). Entrepreneurs' mental health and well-being: A review and research agenda. Academy of Management Perspectives, 32(3), 290-322.

Taylor, P. (2013). The effect of entrepreneurial orientation on the internationalization of SMEs in developing countries. African Journal of Business Management, 7(19), 1927-1937.

Terjesen, S., \& Elam, A. (2012). Women entrepreneurship: A force for growth. In International Trade Forum (pp. 16-18).

The Organisation for Economic Co-operation and Development (OECD). (2013). Guidelines on Measuring Subjective Wellbeing.

Uy, M. A., Song, Z., \& Foo, M. Der. (2013). Joint effects of prior start-up experience and coping strategies on entrepreneurs' psychological well-being. Journal of Business Venturing, 28(5), 583-597.

Vidal, J. A., Chiva, R., \& Lapiedra, R. (2006). A measurement scale for product innovation performance. European Journal of Innovation Management, 9(4), 333-346.

Wiklund, J. (1999). The Sustainability of the entrepreneurial orientation-performance relationship. Entrepreneurship Theory and Practice, 24(1), 37-48.

Xanthopoulou, D. D., Bakker, A. B., Demerouti, E., \& Schaufeli, W. B. (2009). Work engagement and financial returns: A diary study on the role of job and personal resources. Journal of Occupational and Organizational Psychology, 82(1), $183-200$.

Zeng, S. X., Xie, X. M., \& Tam, C. M. (2010). Relationship between cooperation networks and innovation performance of SMEs. Technovation, 30(3), 181-194.

Zhang, X., \& Bartol, K. M. (2010). Linking empowering leadership and employee creativity: The influence of psychological empowerment, intrinsic motivation and Creative process engagement. Academy of Management Journal, 53(1), 107-128.

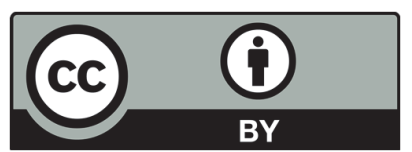

(C) 2020 by the authors; licensee Growing Science, Canada. This is an open access article distributed under the terms and conditions of the Creative Commons Attribution (CC-BY) license (http://creativecommons.org/licenses/by/4.0/). 